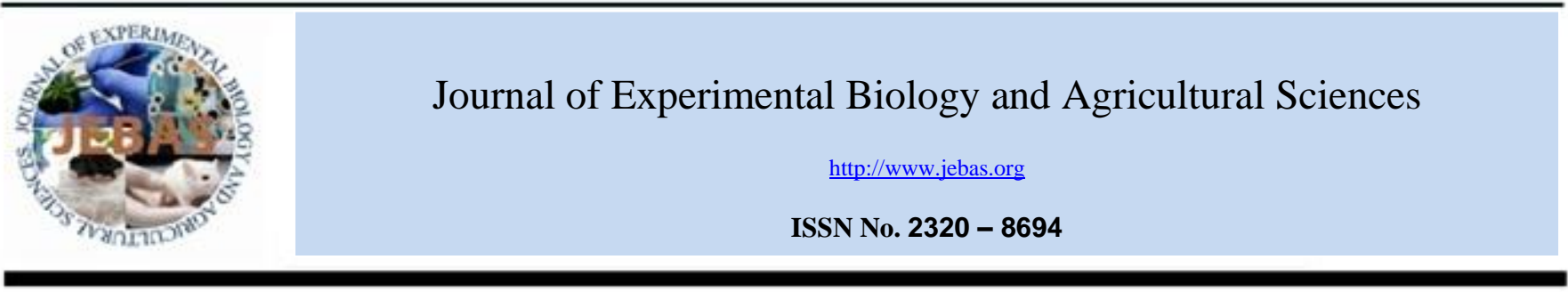

\title{
MALE INFERTILITY: SCREENING OF AZOOSPERMIA FACTOR (AZF) MICRODELETION IN IDIOPATHIC INFERTILE MEN
}

\author{
Prafulla S. Ambulkar and Sunil S. Pande*
}

Rajiv Gandhi Biotechnology Centre, Rashtra Sant Tukadoji Maharaj Nagpur University, LIT campus, Nagpur-33, MS, India.

Received - October 27, 2016; Revision - December 22, 2016; Accepted - February 10, 2017

Available Online - February 28, 2017

DOI: http://dx.doi.org/10.18006/2017.5(1).007.013

KEYWORDS
Y microdeletions
STS markers
AZF Factor
Infertile men

\begin{abstract}
Genetic factors cause about $15 \%$ of male infertility and microdeletions of $\mathrm{Y}$ chromosome is one of the genetic causes in idiopathic infertile men. Azoospermia factors (AZFa, AZFb, and AZFc) on $\mathrm{Yq}$ long arm are most important for spermatogenesis. For analysis of microdeletions in the AZF regions by sequence-tagged-site (STS) PCR is important screening method for infertility. An attempt has been made to evaluate the frequencies of microdeletions of $\mathrm{AZFa}, \mathrm{AZFb}, \mathrm{AZFc}$ in idiopathic cases of azoospermic and oligozoospermic subjects. Total 160 subjects $(90$ oligozoospermia and 70 azoospermia) and 50 control subjects were analyzed in this study. DNA samples were analyzed for microdeletions of Y chromosome by PCR-screening of 18 STS markers from different locus of the $\mathrm{AZFa}, \mathrm{AZFb}, \mathrm{AZFc}$ on Yq and SRY on Yp. The semen analysis was done and infertile men showing normal karyotype only were included in the study. Plasma follicle stimulating hormone (FSH) and leutinizating hormone concentrations were determined to rule out hormonal abnormality. Out of 160 analyzed cases, $17(10.6 \%)$ subjects showed partial deletion of AZF regions, of which deletion in AZFc region was the most common (58.8\%) and it was followed by AZFb and AZFa. The four subjects were shown two or more STS primer deleted sites and overall frequency of Y chromosome microdeletion in our subjects is $10.6 \%$. The sites and sizes of deletions varied among patients. No deletions observed in control subjects. The varied frequencies of $\mathrm{Y}$ microdeletions are reported in infertile men in Indian population. From the results of this study it can be suggest that the frequency of deletions may be affected by study sample size, selection criteria of subjects and different geographical region. So, the screening of $\mathrm{Y}$ microdeletions is necessary along with the chromosomal analysis in case of infertile men.
\end{abstract}

\section{* Corresponding author}

E-mail: dr.sunilpande@ rediffmail.com (Sunil S. Pande)

Peer review under responsibility of Journal of Experimental Biology and Agricultural Sciences.

Production and Hosting by Horizon Publisher India [HPI] (http://www.horizonpublisherindia.in/).

All rights reserved.
All the article published by Journal of Experimental Biology and Agricultural Sciences is licensed under a Creative Commons Attribution-NonCommercial 4.0 International License Based on a work at www.jebas.org.

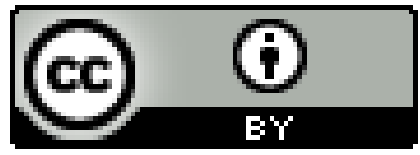




\section{Introduction}

Male infertility affects about $10-15 \%$ of couples trying for pregnancy, and approximately 50\% man responsible for infertility (Boivin et al., 2007). Infertility is defined as the couple inability to conceive after one year of unprotected intercourse (WHO, 2010). Various causative factors of infertility in men include cystic fibrosis, agglutination of sperm, high semen viscosity, non-motile spermatozoa, low volume of ejaculate, varicocele, obstruction of the spermatic ducts, ejaculatory dysfunction, high sperm density, hormonal imbalance, and diabetes (Ambulkar et al., 2014). In 15\% of male infertility cases cause is unknown (idiopathic infertility) (Ambasudhan et al., 2003). Male fertility depends on successful spermatogenesis, in which a number of sex/autosomal genes involved. So, it is evident that deletions or mutations in genes controlling spermatogenesis would result in infertility (Ferlin et al., 2007a).

Molecular studies of Y-chromosome has exposed a region on the short (p) arm specify sex determining region (SRY) that controls sex differentiation and long (q) arm of the $Y$ chromosome having candidate genes that is required for spermatogenesis. Male infertility is associated with long arm of human Y chromosome (Lange et al., 2008). Teipolo \& Zuffardi (1976) reported deletion in non fluorescent euchromatic portion of long arm $\mathrm{Y}$ chromosome in azoospermia male and revealed that these regions contains spermatogenesis controlling candidate genes in human male (Tiepolo \& Zuffardi, 1976). In fact this microdeletion of long arm of the $\mathrm{Y}$ chromosome is involving with spermatogenic failure because of lost spermatogenesis controlling genes (Ferlin et al., 2007a; Ambulkar et al., 2014). Deletion mapping of long arm of $\mathrm{Y}$ chromosome directly provide information of genes related to spermatogenesis, and showed three region of Azoospermia Factors (AZFa, AZFb and AZFc) mapped to Yq11.

These region containing candidate genes which involved in azoospermic or severe oligozoospermic male infertility (Ferlin et al., 2007b). In deletion interval 6 AZF region has been mapped in band q11.23 of the Y chromosome that contains 5 million base pairs (Vogt et al., 1996). The physical mapping of these regions has been estimated to be $3 \mathrm{Mb}$ for AZFc and 1-3 $\mathrm{Mb}$ for $\mathrm{AZFa}$ and $\mathrm{AZFb}$. The important candidate gene in AZFc is the Deleted in Azoospermia (DAZ) cluster, four copies of genes transcribed in the adult testis and expressed exclusively in germ cells (Reijo et al., 1995; Skaletsky et al., 2003). DAZ and RBMY genes families express RNA binding proteins with similar structures related to heterogenous nuclear ribonucleoproteins family (hnRNPG) involved in RNA metabolism, including packaging of RNA, transporting to cytoplasm and splicing to get matured RNA (Reijo et al., 1995; Page et al., 1999). In AZFa region contains DFFRY (Drosophila Fat Facets Related Y) and DBY (DEAD box polypeptide $Y$ ) two main candidate genes. RBMY (RNA-binding motif) gene family whose expression is restricted to the testis is main candidate gene in AZFb region (Chai et al., 1997). RBMY consists of approximately 30 copies of genes and pseudogenes found on both arms of the $\mathrm{Y}$ chromosome, but it is suggested that only functional genes are clustered at the long arm of Yq in the AZFb region (Delbridge et al., 1997).

Microdeletions of AZFc regions are causative factor of spermatogenic impairment. Increasing frequencies of de novo AZF locus microdeletions indicates that the $\mathrm{Y}$ chromosome is highly susceptible to spontaneous loss of spermatogenesis involving genes (Sun et al., 1999). The deletion prone of AZF region has comprised high frequencies of repetitive sequences clustered on $\mathrm{Y}$ chromosome, and exist a Y chromosome haplotype that promote deletions of the AZF regions (Thangaraj et al., 2003; Singh \& Raman, 2009). Thus, de novo deletion may be more susceptible in some infertile individuals than are others. Now a days, intracytoplasmic sperm injection (ICSI) technique is widely accepted procedure to human assisted reproduction in case of male infertility (Silber, 2011). ICSI has changed approach of treatments in males with spermatogenic defects and allowing men to achieve biological paternity of his own children. Transmission of defective AZF sub-region to male child by ICSI has been developed infertility problem in son and lead to familiar infertility (Page et al., 1999).

Due to prognostic value of this type of microdeletion in $\mathrm{Y}$ chromosome, present study investigated the frequency of the Y-chromosome microdeletions in idiopathic infertile men in central region of India and to determine the phenotypes associated with specific deletions.

\section{Materials and Methods}

\subsection{Collection of Blood Samples}

The present study was carried out on 160 idiopathic infertile patients. All these infertile men were showed different semen profile from oligozoospermia $(<20$ million/ml sperm) to azoospermia (absent of sperm in semen) according to semen analyses guidelines of WHO 2010 (WHO, 2010). Total 90 oligozoospermia and 70 non-obstructive azoospermia infertile men were studied and all infertile males had recruited from different laboratories, Urology clinics and IVF centre. History of patients such as Diabetes, Cystic fibrosis, testicular-pathies subjects not taken blood sample. After hormonal analysis remaining blood samples were collected from these centres to perform genetic analysis of subjects. Questioner form was filled up from all infertile patients.

\subsection{DNA extraction}

Human genomic DNA was extracted from peripheral blood lymphocytes using conventional method (Ambulkar et al., 2014) as follow: briefly, $0.5 \mathrm{ml}$ of peripheral blood was collected in vials. 
Table 1 STS-Primers and its sequences for screening of AZF region Y chromosome.

\begin{tabular}{|c|c|c|c|c|}
\hline $\begin{array}{l}\text { STS } \\
\text { marker }\end{array}$ & $\begin{array}{l}\text { Forward } \\
\text { Sequences }\end{array}$ & $\begin{array}{l}\text { Reverse } \\
\text { Sequences }\end{array}$ & $\begin{array}{l}\text { PCR } \\
\text { products }\end{array}$ & Locus \\
\hline sY746 & 5'-TTGACTGCTTATTCTACACAA-3' & 5'-CAGGGGAAATTGGGTTTT-3' & $216 \mathrm{bp}$ & AZFa \\
\hline sY86 & 5'-GTGACACACAGACTATGCTTC-3' & 5'-ACACACACACAGACTATGCTTC-3' & $320 \mathrm{bp}$ & \\
\hline sY84 & 5'-AGAAGGGTCTGAAAGCAGGT-3' & 5'-GCCTACTACCTGGAGGCTTC-3' & $326 \mathrm{bp}$ & \\
\hline DFFRY & 5'-ATGTGGACTATAATTTCTTCCC-3' & 5'-CTGTCGTTCCCTCCTACTGG-3' & $130 \mathrm{bp}$ & \\
\hline sY113 & 5'-GTTCTTTCCACAGCCCATAG-3' & 5'-TGGAACACAATCCAAAATTG-3' & $304 \mathrm{bp}$ & $\mathbf{A Z F b}$ \\
\hline sY118 & 5'-GTACCTCTGCAGGCACTGAT-3' & 5'-ACACAATCCAACCTGGCTAA-3' & $218 \mathrm{bp}$ & \\
\hline sY127 & 5'-GGCTCACAAACGAAAAGAAA-3' & 5'-CTGCAGGCAGTAATAAGGGA-3' & $274 \mathrm{bp}$ & \\
\hline RBMIY & 5'-ATGCACTTCAGAGATACGGGA-3' & 5'-СТСТСТCСАCAAAACCAACAGT-3' & $800 \mathrm{bp}$ & \\
\hline XKRY & 5'-GACACCATGGCTGGAGTTTT-3' & 5'-GGATTGTATGTCCCACCTGC-3' & $200 \mathrm{bp}$ & \\
\hline sY134 & 5'-GTCTGCCTCACCATAAAACA-3' & 5'-ACCACTGCCAAAACTTTCAA-3' & $301 \mathrm{bp}$ & \\
\hline sY143 & 5'-GCAGGATGAGAAGCAGGAT-3' & 5'-CCGTGTGCTGGAGACTAATC-3' & $311 \mathrm{bp}$ & \\
\hline sY153 & 5'-GCATCCTCATTTTATGTCCA-3' & 5'-CAACCCAAAGCACTGAGTA-3' & $139 \mathrm{bp}$ & AZFc \\
\hline sY148 & 5'-AAATGAAAAGATACGAACTC-3' & 5'-GAATCCCACCCAAGAATCTG-3' & $202 \mathrm{bp}$ & \\
\hline sY157 & 5'-CTTAGGAAAAGTGAAGCCG-3' & 5'-CCTGCTGTCAGCAAGATACA-3' & $286 \mathrm{bp}$ & \\
\hline sY255 & 5'-GTTACAGGATTCGGCGTGAT-3' & 5'-CTCGTCATGTGCAGCCAC-3' & $126 \mathrm{bp}$ & \\
\hline sY254 & 5'-GGGTGTTACCAGGAGGCAAA-3' & 5'-GAACCGTATCTACCAAAGCAGC-3' & $380 \mathrm{bp}$ & \\
\hline sY158 & 5'-CTCAGAAGTCCTCCTAATAG-3' & 5'-ACAGTGGTTTGTAGCGGGTA-3' & $231 \mathrm{bp}$ & \\
\hline sY160 & 5'-TACGGGTCTCGAATGGAATA-3' & 5'-TCATTGCATTCCTTTCCCATT-3' & $236 \mathrm{bp}$ & \\
\hline $\begin{array}{l}\text { sY14 } \\
\text { (SRY) }\end{array}$ & 5'-GAATATTCCCGCTCTCCGGA-3' & 5'-GCTGGTGCTCCATTCTTGAG-3' & $476 \mathrm{bp}$ & \\
\hline
\end{tabular}

Table 2 Deleted 17 Azoo/Oligozoospermia cases showed AZF deletion sites and seminal condition.

\begin{tabular}{|lll|}
\hline $\begin{array}{l}\text { Deletion in } \\
\text { cases }\end{array}$ & $\begin{array}{l}\text { Deleted AZF } \\
\text { region }\end{array}$ & Semen type \\
\hline P6 & AZFc & Azoospermia \\
\hline P13 & AZFc & Oligozoospermia \\
\hline P19 & AZFc & Oligozoospermia \\
\hline P27 & AZFb+c & Azoospermia \\
\hline P33 & AZFc & Oligozoospermia \\
\hline P38 & AZFb & Azoospermia \\
\hline P41 & AZFc & Oligozoospermia \\
\hline P53 & AZFc & Oligozoospermia \\
\hline P69 & AZFb+c & Oligozoospermia \\
\hline P75 & AZFa & Azoospermia \\
\hline P89 & AZFa & Azoospermia \\
\hline P103 & AZFb & Azoospermia \\
\hline P109 & AZFc & Oligozoospermia \\
\hline P126 & AZFa $+b$ & Azoospermia \\
\hline P137 & AZFc & Azoospermia \\
\hline P143 & AZFb $+c$ & Azoospermia \\
\hline P156 & AZFc & Oligozoospermia \\
\hline
\end{tabular}

RBC lysis buffer was added to whole blood. It was following by addition of $20 \%$ SDS and proteinase $\mathrm{K}$ and incubated for 2 hrs, at $55^{\circ} \mathrm{C}$. DNA was extracted by phenol chloroform treatment and $3 \mathrm{M}$ sodium acetate and $99.5 \%$ ethanol was added for DNA precipitation. DNA sample was washed in
$70 \%$ ethanol, and dissolved in TE buffer. DNA extracted from each patient was prepared for $100 \mathrm{ng} / \mathrm{ml}$ DNA concentration.

2.3 Sequence tagged sites polymerase chain reaction (STSPCR)

The screening method for microdeletions was based on simplex PCR method using Y-chromosome specific STSs, which corresponded to the AZFa, b and c regions. Eighteen ICMR recommended Yq STS were used: sY746, sY86, sY84, DFFRY (AZFa), sY113, sY118, sY127, RBMIY, XKRY, sY134, sY143 (AZFb), sY153, sY148, sY157, sY255, sY254, sY158, sY160 (AZFc). In addition, the Yp STS sY14 within the SRY gene was tested. Specific primers used for each STS PCR reaction mixture and the expected PCR product lengths are amplified. The analysis of more than three STS loci in each region increases diagnostic accuracy (Table 1), because deletions usually involve more than one STS primer sites loci. Genomic DNA $(2 \mu \mathrm{l})$ was added with $100 \mathrm{mM}$ Tris-CI $(\mathrm{pH}$ 8.3), $5 \mu 1$ 10X PCR assay buffer, $15 \mathrm{mM} \mathrm{MgCl}_{2}, 200 \mathrm{mM}$ of dNTP mix, $0.5 \mathrm{mM}$ of each primer pair, $0.2 \mu \mathrm{l}$ Taq DNA polymerase (NEB, England) in reaction mixture and adjusted to a final volume of $50 \mu \mathrm{l}$ with sterile triple distilled water. The PCRs were performed according to the following programs for all the STS markers: initial denaturation were $94^{\circ} \mathrm{C}$ for $4 \mathrm{~min}$ subsequently 30 cycles at $94^{\circ} \mathrm{C}$ for $30 \mathrm{sec}, 55-58^{\circ} \mathrm{C}$ for $30 \mathrm{sec}$, and $72^{\circ} \mathrm{C}$ for 1 min and a final extension step at $72^{\circ} \mathrm{C}$ for 7 min. 
Table 3 Regionwise Y microdeletions are detected in 17 in oligo/azoospermia infertile patients.

\begin{tabular}{|lll|}
\hline $\begin{array}{l}\text { AZF region } \\
\text { deletion }\end{array}$ & $\begin{array}{l}\text { Frequency } \\
(\mathbf{n = 1 7})\end{array}$ & Percentage \\
\hline AZFa & 1 & $5.88 \%$ \\
\hline AZFb & 2 & $11.76 \%$ \\
\hline AZFc & 10 & $58.82 \%$ \\
\hline AZFa+b & 1 & $5.88 \%$ \\
\hline AZFb+c & 3 & $17.64 \%$ \\
\hline
\end{tabular}

Every PCR reactions were set with two negative controls as one sample without template DNA and one sample of female genomic DNA. In the event of detecting a microdeletion of a Y-specific sequence tagged sites (STSs) with a primer, the PCR assay were repeated thrice for confirmation.

\section{Results}

All infertile men were shown normal cytogenetic profile and were subjected for deletion mapping of $\mathrm{Y}$ chromosome microdeletions. Y chromosome microdeletions were detected and confirmed with 18 STS primer PCR based analysis in 17 subjects (10.6\%) out of the 160 infertile subjects. Out of 17 subjects, $4(23.5 \%)$ were detected with the presence of either two or more deleted STS loci and remaining $13(76.4 \%)$ subjects were shown single STS sties deleted on AZF regions (Figure 1). All deletions were recorded in interstitial region of Yq11 in the AZF locus of $8.8 \%$ (8/90) oligozoospermic and $12.8 \%$ (9/70) azoospermic infertile men (Table 2). No deletions were identified in any of the 50 fertile men. In normal fertile women, negative control, STS failed to amplify. The relatively high proportion of microdeletions (12.8\%) found in 70 azoospermic infertile and (8.8\%) found in 90 oligozoospermic infertile men. The Regionwise deletions observed and the percentages of STS markers in AZF locus are shown in Table 3 (Figure 2). All the infertile men with microdeletions had normal serum testosterone concentrations, and serum FSH and LH concentrations had within normal range.

\section{Discussion}

Spermatogenesis is controlled by a number of genes on sex chromosome and autosomes (Vogt et al., 1996). Long arm of Y chromosome having three important locus, which contains essential candidates genes for regulation of spermatogenesis. Microdeletions in Y-chromosome are known cause of male infertility (Krausz \& Degl'Innocenti, 2006). The incidence of $\mathrm{Y}$ chromosome microdeletions varied with the severity of the spermatogenic defect in infertile males (Massart et al., 2012). Over all $10-15 \%$ of azoospermic and $5-10 \%$ oligozoospermic men show Y microdeletions in idiopathic conditions and till on date STS PCR based technique is used for screening of AZF regions microdeletions on $\mathrm{Y}$ chromosome (Sachdeva et al., 2011; Sen et al., 2013).
Now, the diagnosis of genetic aetiology has important clinical significance because assisted reproductive technology helps infertile couple to overcome infertility problem. Intra cytoplasmic sperm injection (ICSI) is prone for transmission of microdeletions to their offspring (Silber, 2011). Hence, STSPCR based Y chromosome microdeletions screening will provide counselling to infertile couple effectively, regard to the birth of an infertile male offspring (Kuchukaslan et al., 2013; Ambulkar et al., 2015).

In present study, $10.6 \%$ microdeletions was reported in the $\mathrm{Y}$ chromosome in idiopathic oligozoospermic and azoospermic infertile men. In 90 oligozoospermic and 70 azoospermic infertile males had shown $8(8.8 \%)$ patients and $9(12.8 \%)$ patients Y-chromosome microdeletions respectively. Here, in azoospermia patients the frequency of microdeletion is higher than oligozoospermia (Table 2). The reported frequencies of microdeletions of $\mathrm{Yq}$ in different studies range between $2 \%$ and $18 \%$ of males with non-obstractive azoospermia or severe oligozoospermia in India (Ambasudhan et al., 2003; Dada et al., 2004; Sen et al., 2013). In comparison to the statistical data obtained from all the published report to date, some studies reported $20 \%$ of microdeletions in the Y chromosome of infertile males, while others $2 \%$. Further studies had showed an incidence of microdeletions $5.1 \%$ to $9.6 \%$ in the infertile males (Tuttelmann et al., 2007; Ferlin et al., 2007b). On the other hand, in Italy 55\% microdeletions of Y chromosome were found in infertile males (Simoni et al., 2004). Results of present study and prevalence of microdeletions are in accordance with the previously reported results and reported between 10-23\% (Ambasudhan et al., 2003; Thangaraj et al., 2003).

Previously published studies have shown a remarkably variation in the microdeletion frequency. This is due to selection criteria of different patients groups and use of different sets of STS marker (Simoni et al., 2004). On Yq region of AZF microdeletions was directly related with the phase in which spermatogenesis was arrested. Microdeletions of each locus cause spermatogenic arrest at a particular stage because each candidate genes of AZF locus specified a different phase of spermatogenesis (Geoffroy-Siraudin et al., 2007). Testicular histology of Y chromosome microdeletions in azoospermia and oligozoospermia infertile male had shown variable phenotypes of spermatogenesis (Singh \& Raman, 2005). The microdeletions in AZFa region was related with SOC syndrome (absence of germ cells and presence of sertoli cells in the seminiferous tubules) and azoospermia (Mitra et al., 2008). The microdeletion of AZFb was associated with developmental arrest of germ cells and led to meiotic maturation arrest. The microdeletion of AZFc was associated with arrest of germ cells at spermatid stage and hypospermatogenesis with sperm counts (Chai et al., 1997; Delbridge et al., 1997). Therefore, microdeletions of a AZF regions results in abnormal phenotypes in spermatogenesis and candidate genes at each locus act at a specific stage of germ cell differentiation (Ambasudhan et al., 2003; Massart et al., 2012). 


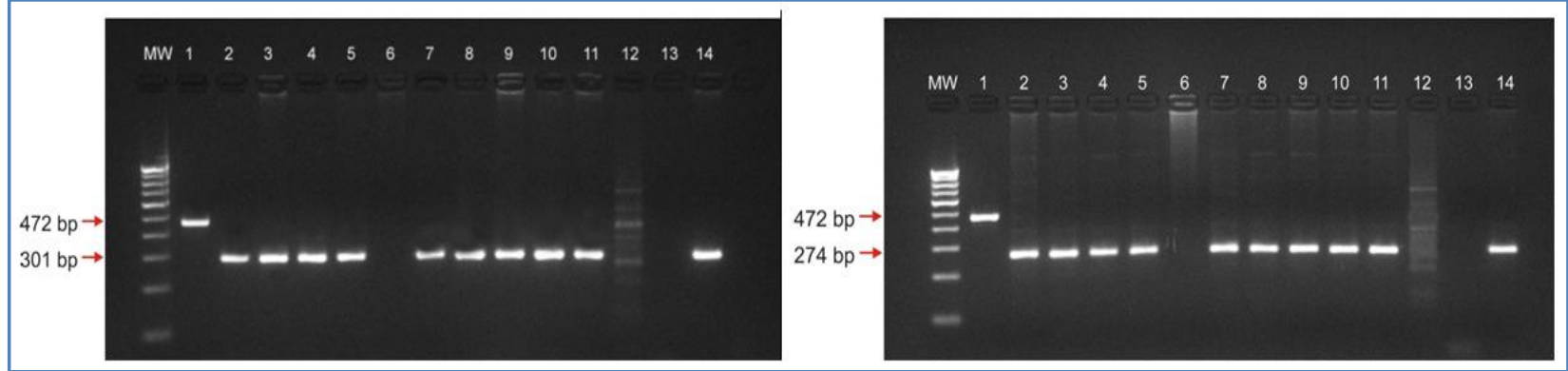

Figure 1 (a \& b) Agarose gel analysis shows microdeletions in STS markers of sY127 and sY134 in lane 6.

$\mathrm{Y}$ chromosome of AZFc region was most frequently deleted sites in infertile males. DAZ (Deleted in azoospermia) is candidate gene of $\mathrm{AZFc}$ region plays important role for spermatogenesis (Zhang et al., 2007). Deletion of AZFc region was detected in ten patients, $58.8 \%(10 / 17)$ of total deleted infertile males. Microdeletions in $\mathrm{AZFb}$ region were detected in $2(11.7 \%)$ infertile males and AZFa region was detected in 1 (5.8\%) infertile males. Deletion of $\mathrm{AZFb}+\mathrm{c}$ and $\mathrm{AZFb}+\mathrm{a}$ regions were detected in $3(17.6 \%)$ and $1(5.8 \%)$ infertile males respectively (Figure 2). Three deletions in AZFc+b and one deletion in $\mathrm{AZFb}+\mathrm{a}$ are overlapping two regions otherwise all microdeletions are occur in interstitial of AZF regions of $\mathrm{Y}$ chromosome. Results of present study showed AZFa and $\mathrm{AZFb}$ are less frequently deleted sites than $\mathrm{AZFc}$ region (Table 3). DAZ is multiple copy number genes which contains higher number of pallindromic repititive sequences in AZFc region. Skaletsky et al. (2003) was reported that reduction of copy number to have an increased risk in infertility (Skaletsky et al., 2003; Sen et al., 2015). Deletion of AZFa and AZFb of Y chromosome can cause azoospermia or severe oligozoospermia (Vogt et al., 1996) and these results showed that all AZFa and $\mathrm{AZFb}$ microdeletions were present in only azoospermic infertile males (Mitra et al., 2008; Ambulkar et al., 2015).

The present study showed that microdeletions in spermatogenesis involving genes of AZF region cause various abnormal phenotypes in infertile males. These results confirmed that before the infertile couple have adapted Intra cytoplasmic sperm Injection or other assisted reproductive techniques, sets of STS markers of AZF regions should be used routinely as diagnostic genetic test to screen for $\mathrm{Y}$ chromosome microdeletions.

\section{Conflict of interest}

Authors would hereby like to declare that there is no conflict of interests that could possibly arise.

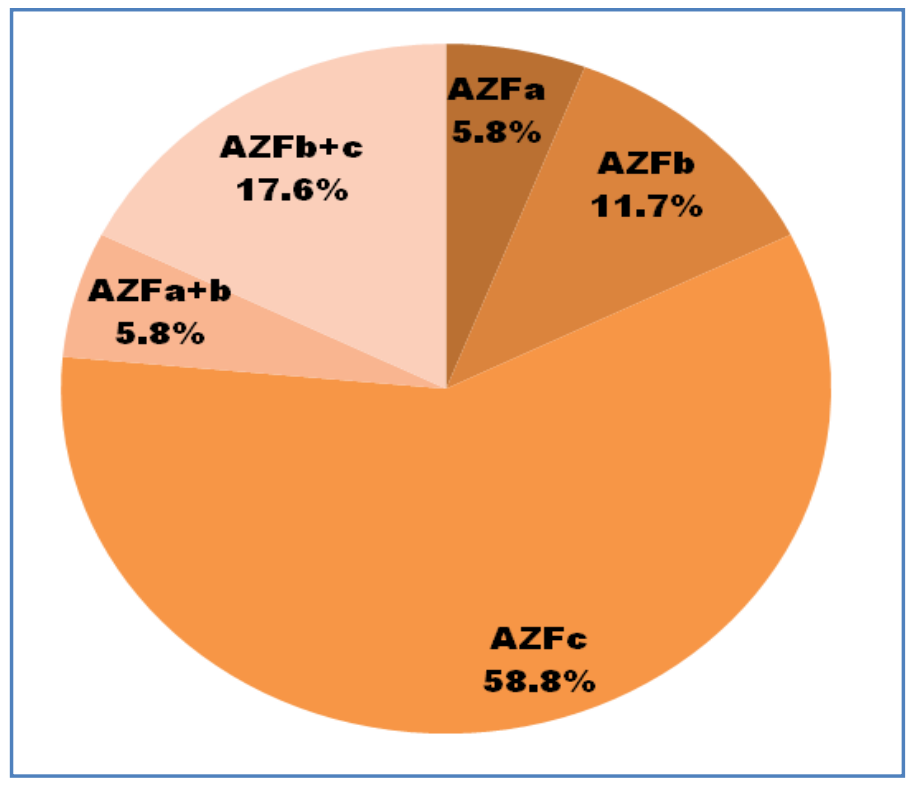

Figure 2: Subject wise percentage of AZF region deletion in 17 subjects. 


\section{References}

Ambasudhan R, Singh K, Agarwal JK, Singh SK, Khanna A (2003) Idiopathic cases of male infertility from a region in India show low incidence of Y-chromosome microdeletion. Journal Biosciences 28: 605-612.

Ambulkar PS, Chaudhary AR, Waghmare JE, Tarnekar AM, Pal AK (2015) Prevalence of Y chromosome microdeletions in Idiopathic Azoospermia cases in central India. Journal of Clinical \& Diagnostic Research 9: GC01-GC04.

Ambulkar PS, Singh R, Reddy MVR, Varma PS, Gupta DO, Pal AK (2014) Genetic Risk of Azoospermia Factor (AZF) Microdeletions in Idiopathic Cases of Azoospermia and Oligozoospermia in Central Indian Population. Journal Clincal Diagnostic Research 8: 88-91.

Boivin J, Bunting L, Collins JA, Nygren KG (2007) International estimates of infertil $\neg$ ity prevalence and treatmentseeking: potential need and demand for infertility medical care. Human Reproduction 22: 1506-1512.

Chai NN, Salido EC, Yen PH (1997) Multiple functional copies of the RBM gene family, a spermatogenesis candidate on the human Y chromosome. Genomics 45:355-361.

Dada R, Gupta NP, Kucheria K (2004) Yq microdeletionsazoospermia factor candidate genes and spermatogenic arrest. Journal Biomolecule Technique 15: 176-183.

Delbridge ML, Harry JL, Toder R, O'Neill RJW, Ma K, Chandley AC, Graves JAM (1997) A human candidate spermatogenesis gene, RBMI, is conserved and amplified on the marsupial Y chromosome. Nature Genetics 15:131-136.

Ferlin A, Arredi B, Foresta C (2007a) Genetic causes of male infertility. Reproduction Toxicology 22: 133-141.

Ferlin A, Arredi B, Speltra E, Cazzadore C, Selice R, Garolla A (2007b) Molecular and clinical characterization of $\mathrm{Y}$ chromosome microdeletions in infertile men: a 10-year experience in Italy. Journal Clinical Endocrinology Metabolism 92: 762-770.

Geoffroy-Siraudin C, Aknin-Seiffer I, Metzler-Guillemain C, Ghalamoun-Slaimi R, Bonzi MF (2007) Meiotic abnormalities in patients bearing complete AZFc deletion of $\mathrm{Y}$ chromosome. Human Reproduction 22: 1567-1572.

Krausz C, Degl'Innocenti S (2006) Y chromosome and male infertility: update. Frontier Biosciences 11: 3049-3061.

Kuchukaslan AS, Cetintas VB, Altintas R, Vardarli AT, Mutlu Z, Ulukas M (2013) Identification of $\mathrm{Y}$ chromosome microdeletions in infertile Turkish men. Turkish Journal of Urology 39: 170-174.
Lange J, Skaletsky H, Bell GW, Page DC (2008) MSY Breakpoint Mapper, a database of sequence-tagged sites useful in defining naturally occurring deletions in the human $\mathrm{Y}$ chromosome. Nucleic Acids Research 36: D809-D814.

Massart A, Lissens W, Tournaye H, Stouffs K (2012) Genetic causes of spermatogenic failure. Asian Journal Andrology 14: 40-48.

Mitra A, Dada R, Kumar R, Gupta NP, Kucheria K, Gupta SK (2008) Screening for Y-chromosome microdeletions in infertile Indian males: Utility of simplified multiplex PCR. Indian Journal of Medical Research 127: 127-132.

Page DC, Silber S, Brown LG (1999) Men with infertility caused by AZFc deletion can produce sons by intracytoplasmic sperm injection, but are likely to transmit the deletion and infertility. Human Reproduction 14: 1722-1726.

Reijo R, Lee TY, Salo P, Alagappan R, Brown LG, Rosenberg M (1995) Diverse spermatogenic defects in humans caused by Y chromosome deletions encompassing a novel RNA-binding protein gene. Nature Genetics 10: 383-393.

Sachdeva K, Saxena R, Majumdar A, Chadda S, Verma IC (2011) Use of ethnicity-specific sequences tag site markers for Y chromosome microdeletion studies. Genetics Test \& Molecular Biomarkers 15: 451-459.

Sen S, Ambulkar P, Hinduja I, Zaveri K, Gokral J, Pal A, Modi D (2015) Susceptibility of gr/gr rearrangements to azoospermia or oligozoospermia is dependent on DAZ and CDY1 gene copy deletions. Journal of Assisted Reproduction \& Genetics $32 ; 1334-1341$.

Sen S, Pasi AR, Dada R, Shamsi MB, Modi D (2013) Y chromosome microdeletions in infertile men: prevalence, phenotypes and screening markers for the Indian population. Journal of Assisted Reproduction and Genetics 30: 413-422. DOI: $10.1007 / \mathrm{s} 10815-013-9933-0$

Silber SJ (2011) The $\mathrm{Y}$ chromosome in the era of intracytoplasmic sperm injection: a personal review. Fertility \& Sterility 95: 2448e1-2448e5.

Simoni M, Bakker E, Krausz C (2004) EAA/EMQN best practice guidelines for molecular diagnosis of $\mathrm{y}$-chromosomal microdeletions: State of the art. International Journal of Andrology 27: 240-249.

Singh K, Raman R (2005) Male infertility: Y chromosome deletion and testicular aetiology in cases of azoo/oligospermia. Indian Journal of Experimental Biology 43:1088-1092.

Singh K, Raman R (2009) Y-haplotypes and idiopathic male infertility in an Indian population. Indian Journal of Human Genetics 15: 19-22. 
Skaletsky H, Kuroda-Kawaguchi T, Patrick JM, Minx PJ, Cordum HS, Hillier L (2003) The male specific region of the human $\mathrm{Y}$ chromosome is a mosaic of discrete sequence classes. Nature 423:825-837.

Sun C, Skaletsky H, Birren B, Devon K, Tang Z, Silber S, Oates R, Page DC (1999) An azoospermic man with a de novo point mutation in the $\mathrm{Y}$ chromosomal gene USP9. Nature Genetics 23:429-432.

Thangaraj K, Gupta NJ, Pavani K, Reddy AG, Subramainan S, Singh L (2003) Y Chromosome Deletions in Azoospermic Men in India. Journal of Andrology 24: 588-597.

Tiepolo L, Zuffardi O (1976) Localization of factors controlling spermatogenesis in the nonfluorescent portion of the human Y chromosome long arm. Human Genetics 34: 119124.
Tuttelmann F, Rajpert-De, Meyts E, Nieschlag E, Simoni M (2007) Gene polymorphisms and male infertility--a metaanalysis and literature review. Reproduction Biomedicine Online 15: 643-658.

Vogt PH, Edelmann A, Krisch S, Henegariu O, Hirschmann P, Kiesewetter F (1996) Human Y chromosome azoospermia factors (AZF) mapped to different subregions in Yq11. Human Molecular Genetics 5: 233-243.

World Health Organization (2010) WHO laboratory manual for the examination and processing of human semen. 2010; 5th ed. United Kingdom, Cambridge University Press.

Zhang F, Lu C, Li Z, Xie P, Xia Y, Zhu X (2007) Partial deletions are associated with an increased risk of complete deletion in AZFc: a new insight into the role of partial AZFc deletions in male infertility. Journal Medical Genetic 44: 437444. 